\title{
Influencing factors on the implementation of forest reserves in Switzerland
}

\section{Conference Paper}

\section{Author(s):}

Kaeser, Alexandra; Zimmermann, Willi

Publication date:

2014-12

Permanent link:

https://doi.org/10.3929/ethz-b-000075567

Rights / license:

In Copyright - Non-Commercial Use Permitted

Originally published in:

Biodiversity and Conservation 23(14), https://doi.org/10.1007/s10531-014-0776-5 


\title{
Influencing factors on the implementation of forest reserves in Switzerland
}

\author{
Alexandra Kaeser • Willi Zimmermann
}

Received: 21 March 2014/Revised: 15 July 2014/ Accepted: 2 August 2014/

Published online: 20 August 2014

(C) Springer Science+Business Media Dordrecht 2014

\begin{abstract}
In 1999, an international expert team found the neglect of biodiversity issues in Swiss forest policy to be one of its biggest weaknesses. Influenced by this scientific assessment, the Federal Forest Agency developed forest reserve guidelines with measurable objectives in cooperation with the constituent states (cantons). To assess the outcomes of the Swiss forest reserve concept, we surveyed cantons' implementation degree in 2011. In a previous paper, Kaeser et al. (For Policy Econ 3:6-13, 2013) discussed the survey's results from the perspective of new forms of governance in Swiss biodiversity policy. However, the use of different governance approaches could only partly account for the differences between the cantons' forest reserve areas. As a continuation of this study, the present paper contributes to the discussion about the influencing factors on the implementation of forest reserves in Swiss cantons. For this purpose, we examine the effect of institutional drivers, public policies, property rights and user conflicts in 22 Swiss cantons on their forest reserve areas by using a multiple regression. The effect of financial conditions and the share of protective forest of the cantons on forest reserves is statistically significant. The findings indicate that the potential for forest reserves in protective forests in the mountains has been neglected so far. A combination of forest reserves and protective forests could result in a win-win-situation of 'less effort for the management of protective forest' and 'more biodiversity'.
\end{abstract}

Keywords Forest conservation - Forest reserves - Protective forest - Forest ownership · Switzerland · Implementation

\section{Introduction}

Forest reserves are an important tool to promote biodiversity in forests. By protecting the forests from human intervention, old trees and dead wood accumulate and provide habitat

A. Kaeser $(\bowtie) \cdot$ W. Zimmermann

ETH Zurich, Institute for Environmental Decisions, Zurich, Switzerland

e-mail: akaeser@env.ethz.ch 
for beetles, fungi, etc. Hence, the purpose of delimiting forest reserves is to facilitate the natural development of forests and to foster biodiversity; but they also serve as a place for recreation, education and research (Bolliger et al. 2012, p. 202). Forest reserves are essential for basic scientific research as well as for research on biodiversity conservation (in particular regarding dead wood), on the effectiveness of non-managed forests as protective forests and on efficient forest management (Bugmann et al. 2011, p. 57). Much can be learned about near-natural forest management by observing the dynamics in forest reserves. This highlights the importance of forest reserves, emphasizing why they should be supported. To promote forest reserves, a state may launch a forest reserve policy (with clear objectives and instruments).

Policies are used to steer certain social conflicts or processes. The question whether state regulation should declare a forest as a forest reserve or not presents such a conflict. This socio-political objective can usually be achieved with either a regulatory instrument (commands and prohibitions) or with financial incentives and compensation payments (subsidies). In a constitutional state, it goes without saying that both the task (creation of forest reserves) and the provided instruments are governed by the law (principle of legality of government action cf. Häfelin et al. 2010, p. 84). The thereby created regime is steered through binding decisions made by the political-administrative actors (Knoepfel 2003, p. 53). In this sense, public policies and the administration play an important role in forest policy, but they are certainly not the only ones influencing the delimitation of forest reserves. In order to promote forest reserves, it is also necessary to figure out who the other "drivers" are. For example, public policies are only effective if they address a target group that has the rights to act in terms of ownership (Knoepfel et al. 2001, p. XIII).

Our study takes place in Switzerland, where $71 \%$ of the forest area are public forests with various public owners such as the Confederation, the cantons, the municipalities, the civil communities, the corporations/cooperatives, the church communities, etc. (cf. BAFU 2013, pp. 16-17). This share of public forest is rather high in comparison to other European countries (EU-average of private forest: $65 \%$, Germany about $44 \%$ private forest (Mutz 2007, p. 285); Austria: around $80 \%$ private forest (Weiss et al. 2007, p. 293)). This high share of public forest and the very heterogeneous forest owners makes the case of Switzerland remarkable. Also noteworthy is the small parceled private forest $(\varnothing 1.37$ ha per private forest owner; BAFU 2013, p. 70), the geography and the environmental conditions of the Swiss forest. We find forests of the colline, sub montane, montane and sub alpine altitudinal zones. Moreover, roughly half of the Swiss forest is mountain forest (54\%; Brändli 2010, p. 49). Thus, protective forests against natural hazards have a high priority in Swiss forest policy.

In Swiss forest policy, the support of forest reserves can be construed as an explicit objective, combined with adequate instruments, since the 1990s. In a previous paper, Kaeser et al. (2013) assessed the policy design of forest reserve policy and its outcomes (forest reserve areas) in the cantons. The data include the forest reserves as a percentage of the cantonal forest area, which were collected through a survey of the cantonal head foresters in 2011. The results show that the forest reserve areas have increased considerably in the last years in the cantons, which 'suggests that the governance elements (e.g. cooperative steering forms, voluntary agreements and subsidies) used in the implementation have proved to be successful' (Kaeser et al. 2013, p. 12). This indicates that the implementation is on the "right track", i.e. as intended by the policy. However, room for improvement remains, especially regarding the delimitation of large forest reserves. Although new forms of governance have been applied in most of the cantons, the cantons' 
total forest reserve areas vary quite significantly from each other in size. The survey of 2011 provides initial indications of possible influencing factors, such as the ownership structure, the financial condition of the cantons, the organization of the administration and the amount of financial incentives. It appears that several factors must be decisive for the establishment of legally binding forest reserves.

The present study analyzes the effect of such presumably influencing factors on the forest reserves. It is structured as follows: First, we provide a brief overview of the Swiss forest reserve policy. We delineate our research design and formulate our questions and hypotheses. We outline our method and then we present the results. Subsequently, we discuss the major findings of the analysis by taking into account expert knowledge from seven cantonal head foresters of mainly pre alpine cantons and finally draw conclusions.

\section{Background of the Swiss forest reserve policy}

Swiss forest reserve policy is a rather new biodiversity policy, originating in the 1990s. The revision of the Federal Law on Forest (SR 921.0) in 1991 led to an inclusion of conservation concerns in forest policy ${ }^{1}$ (Zingerli and Zimmermann 2006, p. 10). This made it possible 'to renounce forestry management in certain cases' (Kägi 2002, p. 277). The adoption of the Ordinance on Forest (SR 921.01) followed in 1992 and set an ensured 'long-term existence' of forest reserves as a general condition for the financial support of forest reserves. ${ }^{2}$ Based on these legal norms, the Federal Forest Agency developed a national forest reserve concept (Konzept Waldreservate Schweiz; BUWAL 1998 ) in 1998. In 1999, an international expert team assessed the sustainability of Swiss forest policy (SAEFL 1999). This sustainability assessment found the neglect of biodiversity issues and a lack of forest reserves to be the biggest weakness of Swiss forest policy (Kissling-Näf 2000, p. 477; Schärer and Jacobi 2000, p. 486). In order to strengthen the conservation of biological diversity in forest ecosystems (Helsinki Criterion 4 cf. Kissling-Näf 2000, p. 476; MCPFE 1993), the Federal Forest Agency delineated forest reserve guidelines (Leitsätze einer „Waldreservatspolitik Schweiz“; BUWAL and Eidg. Forstdirektion 2002) in cooperation with the constituent states (cantons). Together with the national forest reserve concept these guidelines form the main components of Swiss forest reserve policy.

Swiss forest reserve policy contains qualitative requirements as well as quantitative objectives. The former include protection of threatened forest ecosystems and the promotion of rare tree species/ecologically valuable structures (BUWAL 1998, p. 66). The latter involve the objective of having $10 \%$ of the forest area be forest reserves by 2030 (half of them natural forest reserves without forestry interventions) and 30 large forest reserves (of more than 500 ha) should be delimited by that deadline (BUWAL and Eidg. Forstdirektion 2002).

\footnotetext{
${ }^{1}$ Forest Law of 1991: 'the cantons may set aside forest reserves large enough to ensure the conservation of the species diversity of flora and fauna' (Article 20 para 4) and 'the Confederation shall provide financial support of up to 50 per cent of the costs incurred for protective measures for the upkeep of forest reserves' (Article 38 para 3).

${ }^{2}$ Forest Ordinance of 1992: 'Financial support shall be paid (..) for the protection or upkeep of forest reserves whose long-term existence is ensured in zoning plans and by means of a contract' (Article 49 para $1)$.
} 
In the wake of a new system of financial equalization (NFE) ${ }^{3}$ in 2006 (AS 2007 5779), a new article on 'Biological diversity of the forest' ${ }^{4}$ was created in the Forest Law providing incentives for forest biodiversity in general, and for forest reserves in particular, 'as global contributions' of the Confederation 'on the basis of programme agreements concluded with the cantons' (Article 38 para 2 a). In 2007, the article on forest reserves of the Forest Ordinance was replaced by an article on 'Biological diversity of the forest' ${ }^{5}$ (SR 921.01; AS 2007 5823). This new article on forest biodiversity specified the conditions for global financial support for biodiversity measures such as forest reserves. This article also included a cooperative approach, i.e. negotiations between the Federal Office and the cantons.

\section{Research design, hypotheses and methods}

The present study follows the institutional resource regime (IR) approach (Knoepfel et al. 2003). This so called IR approach describes the context of institutions, actors and the natural resource (with its goods and services), as well as user conflicts. Under the umbrella term 'institutions', this approach combines property rights and public policies. As a consequence, it considers the importance of different ownership structures as well as the effect of policy instruments on natural resources. The sustainable use of the natural resource, such as the forest, is inter alia influenced by specific policies (forest use versus forest protection), property rights/ownership of the resource and the organization of the administration. For a sustainable management of the forest, it is essential to understand how institutions and user conflicts affect the delimitation of forest reserves. With respect to user conflicts, newly available data on protective forest (Losey and Wehrli 2013) from the Federal Office for the Environment provide us the opportunity to test the relationship between forest reserves and protective forest. By focusing on the impact of institutions and user conflicts on forest reserves, we derive two main hypotheses:

a) The institutional framework has a substantial impact on the establishment of forest reserves.

b) The highly subsidized protective function of forests competes with forest reserves for land (as a conflicting service).

As in the paper of Kaeser et al. (2013), we define the cantons as the unit of analysis and the dependent variable is the outcome of the implementation, i.e. 'delimited forest reserve area'. In order to test hypothesis (a), we decided to focus on the following IR components (cf. Knoepfel et al. 2003, p. 10): instruments, implementation actors/arrangement and the property rights/ownership structure of the target groups. Accordingly and based on the insights from our former study (cf. introduction), we derived several (presumably

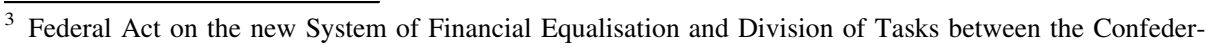
ation and the Cantons.

${ }^{4}$ Forest Law of 1991 (Status 2008), Article 38: 'the Confederation shall provide financial assistance for measures that contribute to the conservation and improvement of biological diversity in the forest, in particular for:' (para 1) 'the protection and maintenance of forest reserves and other ecologically valuable forest habitats' (para 1 a).

${ }^{5}$ Forest Ordinance of 1992 (Status 2011), Article 41: The amount of financial support is 'based on the number of hectares of forest reserves that are to be designated and maintained (para 1 a)', 'negotiated between the Federal Office and the canton concerned (para 2)', 'allocated, if the protection (...) is guaranteed contractually or in any other suitable way (para 3$)^{\text {c }}$.
} 
influencing) independent variables for the statistical analysis within the thematic field of institutions (hypothesis a) and conflicting natural resources' services (hypothesis b), which include:

a) Implementation actors/arrangement, i.e. the 'financial condition' of the cantons and their 'integration of administration'; the instrument 'financial incentives'; the property rights/ownership structure of the target group, i.e. the 'ownership structure' of the forest owners

b) Natural resources' services such as the 'protective function' of forests (against natural hazards)

For each of the above mentioned five independent variables, we formulated one question (labeled A-E) and developed a hypothesis (1-5), which are summarized in Table 1. Our first hypothesis is based on the assumption that 'richer' states spend more money on biodiversity than 'poorer' states (e.g. James et al. 1999). And higher financial incentives for biodiversity can lead to more nature conservation in forests (e.g. Iftekhar et al. 2014; Boon et al. 2010), which provides the basis for our second hypothesis. Third, we hypothesize that conservation issues handled within the same administrative unit as the protection against natural hazards have a better chance of being implemented since 'articulating priorities across different administrative units [...] remains a serious challenge' (Schatz et al. 2014, p. 75). Moreover, the establishment of large forest reserves is constrained by the private forest's small management units (Angst 2012, p. 55) and the attitudes/motivations of private forest owners play an important role for promoting forest biodiversity (e.g. Horne 2006; Belin et al. 2005). This indicates that 'property matters', which is expressed in our fourth hypothesis. Fifth, we assume that only few forest reserves are delimited in protective forest. In the Alps, protective forests (against natural hazards) could be increasingly included into the forest reserve network (Bolliger et al. 2012, p. 208).

In order to test the hypotheses of Table 1, we conducted a statistical analysis of 22 cantons, based on data from a former survey and other sources (Swiss forestry statistics, Project SilvaProtect-CH, etc.). We performed statistical data analysis, in the form of a multiple regression, using the program IBM SPSS Statistics 20. In the analysis we excluded the data from the half cantons Basel-Landschaft and Basel-Stadt, because these two half cantons shared data for the forest reserves, but not for the other data used in the analysis. Furthermore, no data on forest reserves were available from the 2011 study for the canton of Schaffhausen and the half canton of Appenzell Inner Rhodes. Thus, the present study draws on data from 22 instead of 26 (half) cantons in Switzerland in the statistical analysis, based mostly on existing data sources (cf. Table 2).

\section{Results}

Variance in forest reserves between the cantons was partitioned into the following components stipulating the regression equation $\mathrm{y}=4.927+0.060 \mathrm{x}_{1}-0.030 \mathrm{x}_{2}+1.963 \mathrm{x}_{3}-$ $0.083 \mathrm{x}_{4}-0.106 \mathrm{x}_{5}$, where $\mathrm{y}$ is forest reserves (in hectares), $\mathrm{x}_{1}$ is the financial condition of the canton (resource index), $\mathrm{x}_{2}$ is the financial incentives for forest biodiversity (Swiss francs per hectare), $x_{3}$ is the integration of administration within the cantonal forest office (three categories: $0,1,2$ ), $\mathrm{x}_{4}$ is the ownership structure (private forest as percentage of the cantonal forest area) and $x_{5}$ is the protective function of forests (protective forest as percentage of the cantonal forest area). The descriptive statistics are displayed in Table 3. On average $6 \%$ of the cantons' forest are forest reserves. The average canton has a resource index of 95 , financial 


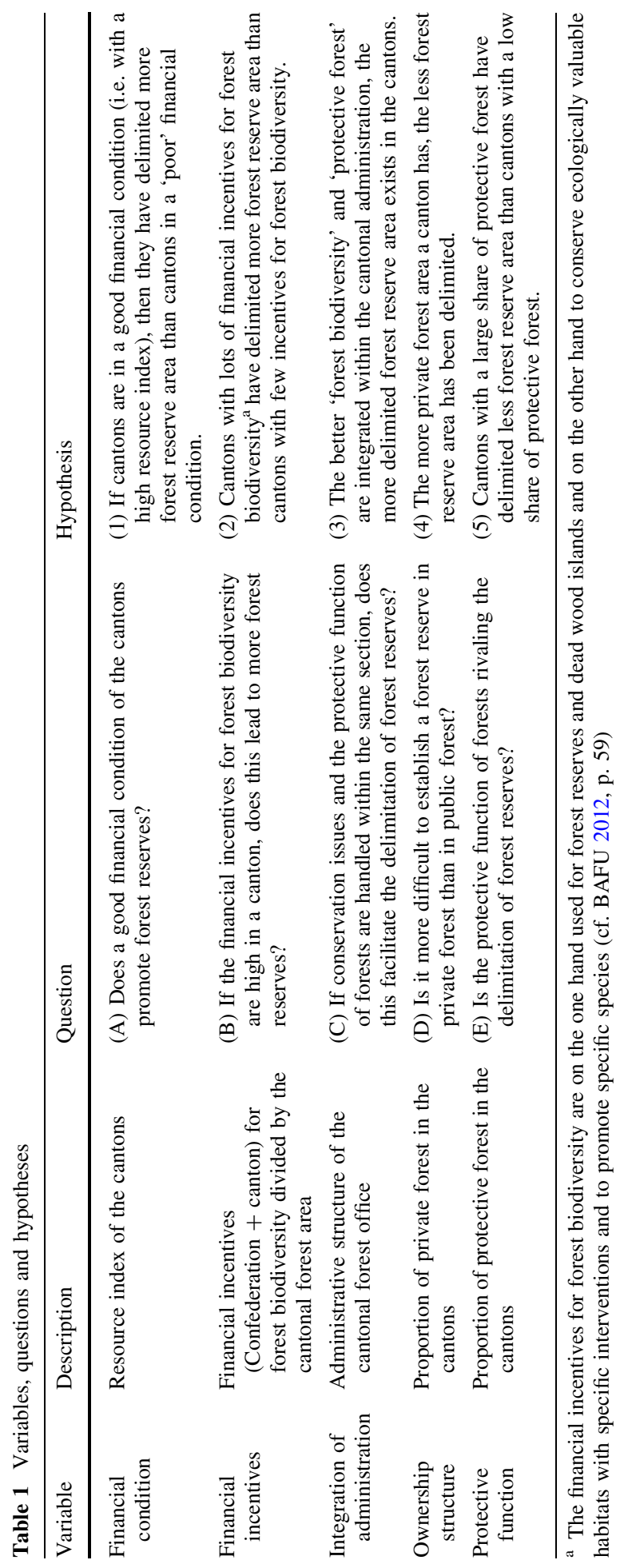


Table 2 Data sources of the variables

\begin{tabular}{|c|c|}
\hline Variable & Data source \\
\hline orest reserves & Kaeser et al.(2013, p. 11) \\
\hline inancial condition & $\begin{array}{l}\text { Swiss Federal Statistical Office and Federal finance administration in 'Education } \\
\text { finances (edition 2012)' (BFS2012, p. 56) of the series 'Statistics of Switzerland' }\end{array}$ \\
\hline Financial incentives & $\begin{array}{l}\text { Federal Office for the Environment and cantons in the yearbooks of forest and } \\
\text { wood 2009-2012 (BAFU 2009, p. 73, 2010, p. 71, 2011, p. 62, 2012, pp. 14/64) }\end{array}$ \\
\hline $\begin{array}{l}\text { Integration of } \\
\text { administration }\end{array}$ & $\begin{array}{l}\text { Analysis }{ }^{\mathrm{a}} \text { of administrative structures in } 2011 \text { (based on the cantonal forest } \\
\text { administration websites) }\end{array}$ \\
\hline Ownership structure & $\begin{array}{l}\text { Swiss forestry statistics in the yearbook of forest and wood } 2012 \text { of the Federal } \\
\text { Office for the Environment (BAFU 2012, p. 14) }\end{array}$ \\
\hline Protective function & Project SilvaProtect-CH (Losey and Wehrli 2013, p. 20) \\
\hline \multicolumn{2}{|c|}{$\begin{array}{l}\text { analysis In a first step, we analyzed for each canton which department, office, section and subsection deal } \\
\text { with 'nature conservation in the forest respectively forest ecology' and 'protective forest'. The analysis } \\
\text { showed for all cantons that these two topics are located in the same department of the canton and the same } \\
\text { office, i.e. the cantonal forest office. If 'nature conservation in the forest respectively forest ecology' and } \\
\text { 'protective forest' were dealt with in different sections or subsections, the cantons got only one point for } \\
\text { integration. If this was not the case, the cantons got two points for integration. Then, categories for the } \\
\text { statistical analysis were derived from this }\end{array}$} \\
\hline
\end{tabular}

Table 3 Descriptive statistics $(\overline{\mathrm{x}}=$ mean; $\mathrm{SD}=$ standard deviation; $\mathrm{CV}=\mathrm{SD} / \mathrm{mean} \times 100 ; n=$ number of cantons)

\begin{tabular}{lrrrr}
\hline Variable & \multicolumn{1}{c}{$\overline{\mathrm{x}}$} & \multicolumn{1}{c}{ SD } & CV & $n$ \\
\hline Forest reserves & 6.130 & 4.420 & 72.104 & 22 \\
Financial condition & 94.860 & 37.851 & 39.902 & 22 \\
Financial incentives & 20.428 & 14.471 & 70.839 & 22 \\
Integration of administration & 1.590 & 0.503 & 31.635 & 22 \\
Ownership structure & 32.770 & 19.009 & 58.007 & 22 \\
Protective function & 40.730 & 26.637 & 65.399 & 22 \\
\hline
\end{tabular}

Source Own calculation based on different data sources indicated in Table 2

incentives of 20 Swiss francs per hectare for forest biodiversity, and a rather integrated forest administration (1.59) and $41 \%$ protective forest. In addition, the coefficient of variance (CV) shows that the variable of administrative integration varies the least across the cantons; followed by the financial condition, ownership structure and protective function. The two variables financial incentives and forest reserves have variation coefficients of more than $70 \%$, which indicates that the data is quite dispersed.

The linear relationships between the different variables are shown in Table 4. The financial incentives correlate positively with the financial condition of the cantons $(p \leq 0.01)$ and with forest reserves $(p=0.047)$. A positive correlation is also found between forest reserves and the financial condition of the cantons $(p \leq 0.01)$. This shows that cantons in a good financial condition have higher financial incentives (for forest biodiversity), both of which indicate a higher share of forest reserves. The protective function correlates negatively with forest reserves $(p=0.018)$, financial incentives $(p=0.011)$ and ownership structure $(p=0.019)$. Or in other words, the more protective 
Table 4 Pearson correlation matrix of the variables $(n=22$ cantons)

\begin{tabular}{|c|c|c|c|c|c|c|}
\hline Variables & 1 & 2 & 3 & 4 & 5 & 6 \\
\hline 1.Forest reserves & 1.000 & $0.551 * *$ & $0.365^{*}$ & 0.076 & -0.044 & $-0.449 *$ \\
\hline 2.Financial condition & & 1.000 & $0.562 * *$ & 0.052 & 0.089 & -0.172 \\
\hline 3.Financial incentives & & & 1.000 & -0.303 & 0.195 & $-0.488 *$ \\
\hline 4.Integration of administration & & & & 1.000 & 0.017 & 0.311 \\
\hline 5.Ownership structure & & & & & 1.000 & $-0.445^{*}$ \\
\hline 6.Protective function & & & & & & 1.000 \\
\hline
\end{tabular}

Source Own calculation based on different data sources indicated in Table 2

$* p \leq 0.05, * * p \leq 0.01, * * * p \leq 0.001$

Table 5 Dependence of forest reserves on the financial condition, financial incentives, integration of administration, ownership structure and protective function $(\mathrm{n}=22$ cantons)

\begin{tabular}{lllll}
\hline & \multicolumn{2}{l}{ Forest reserves } & & \\
\cline { 2 - 5 } & $b$ & SE & $p$ & VIF \\
\hline Intercept & 4.927 & 3.714 & 0.203 & 1.600 \\
Financial condition & 0.060 & 0.024 & $0.024 *$ & 2.082 \\
Financial incentives & -0.030 & 0.072 & 0.683 & 1.269 \\
Integration of administration & 1.963 & 1.626 & 0.245 & 1.289 \\
Ownership structure & -0.083 & 0.043 & 0.073 & 1.693 \\
Protective function & -0.106 & 0.035 & $0.009 * *$ &
\end{tabular}

$n=22, R^{2}=0.568$. Source Own calculation based on different data sources indicated in Table 2

$* p \leq 0.05, * * p \leq 0.01$

forest a canton has, the less forest reserves and private forest are found and few financial incentives are paid for forest biodiversity.

Table 5 summarizes the results on whether the five independent variables have a statistically significant effect on forest reserves. We found a significant effect between the 'financial condition' of the cantons and the delimited forest reserve area in the cantons. The same is true for the dependency of forest reserve area on the protective function, i.e. the amount of protective forest in the cantons. In contrast, neither the 'financial incentives' for forest biodiversity (per hectare), the 'integration of administration' (within the cantonal forest office) nor the 'ownership structure', i.e. the share of private forest in the cantons, significantly affected the forest reserves.

The variance inflation factors (VIF) are displayed in Table 5, the predictors being moderately correlated. The variable of financial incentives has the highest VIF, which is only slightly above 2 . Thus, we do not expect collinearity to be problematic.

Figure 1 shows the forest reserves in relation to the financial condition of the cantons. The financial strength of a canton is illustrated by the resource index, which reflects the taxable resources (income, assets, etc.) of a canton (BFS 2012, p. 16; cf. SR 613.11). The higher the resource index, the financially stronger the canton. The cantons with large cities, 


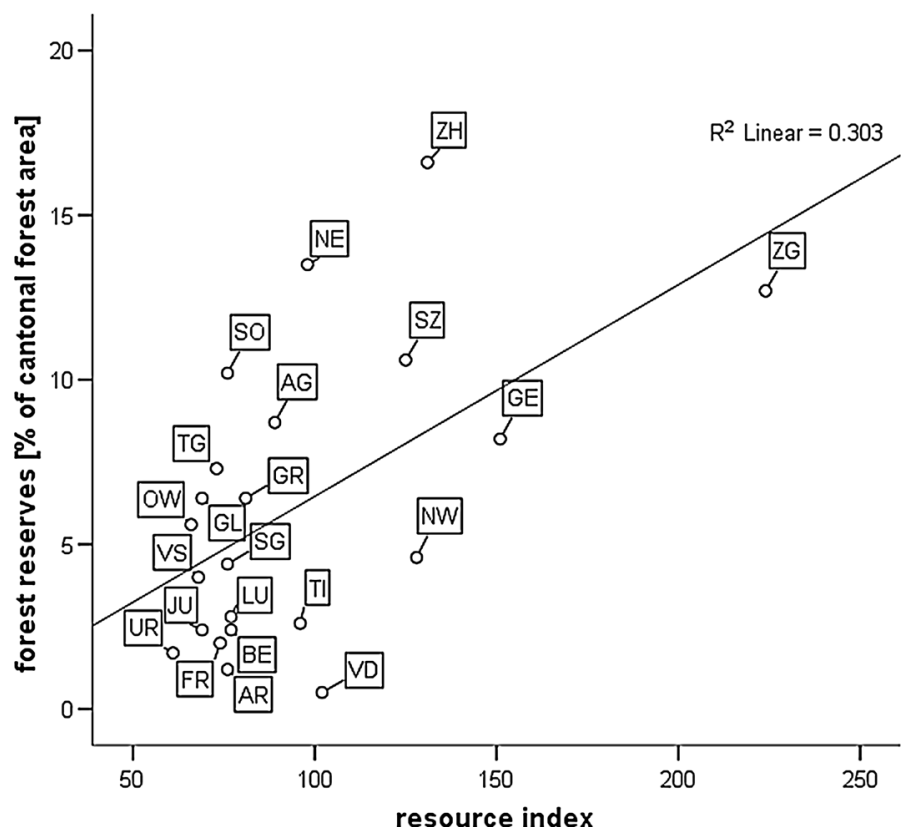

Fig. 1 Dependence of forest reserves on the financial condition (resource index 2009) ( $n=22$ cantons). Source Own illustration based on data from Kaeser et al. (2013) and BFS (2012, p. 56)

i.e., Zurich ( $\mathrm{ZH})$ and Geneva (GE), and the cantons with the lowest tax load, i.e., Nidwalden (NW), Schwyz (SZ) and Zug (ZG) (cf. EFD 2013, p. 2), have a high resource index (Fig. 1).

The effect of the financial condition (resource index) on the forest reserves is statistically significant (cf. Table 5). Thus, the higher the resource index, the more forest reserve areas. In other words, cantons in a good financial condition (i.e. with a high resource index) have delimited more forest reserve area than cantons with a 'poor' financial condition.

Figure 2 illustrates the relationship between the financial incentives for forest biodiversity (per hectare) and the delimited forest reserve area. The finding that the cantons with less than $5 \%$ forest reserve area do not have very high amounts of financial incentives per hectare forest is noteworthy. However, the dependency of forest reserves on financial incentives for forest biodiversity (per hectare), for the average of the years 2009-2011 was statistically not significant (cf. Table 5).

The forest ownership, i.e. the share of private forest, had a negative but not a significant effect on forest reserves in the multiple regressions (cf. Table 5). In this context it is noteworthy that only the cantons Appenzell Outer Rhodes (AR), Lucerne (LU) and Thurgau (TG) have more private forests than public forests (cf. Fig. 3). But if we consider only the (very) mountainous cantons Glarus (GL), Grisons (GR), Obwalden (OW), Ticino (TI), Uri (UR) and Valais (VS), we can say that the more private forest there is, the lower the share of forest reserves $\left(R^{2}=0.459\right)$. In the high mountains, it seems rather unlikely to have high shares of private forest and protective forest.

Figure 4 indicates that the topography of the cantons seems to have an indirect effect on the forest reserves. The cantons of the lowlands such as Aargau (AG), Geneva (GE), Solothurn (SO), Thurgau (TG) and Zurich (ZH) (cf. Brändli 2010, p. 27)—which have less 


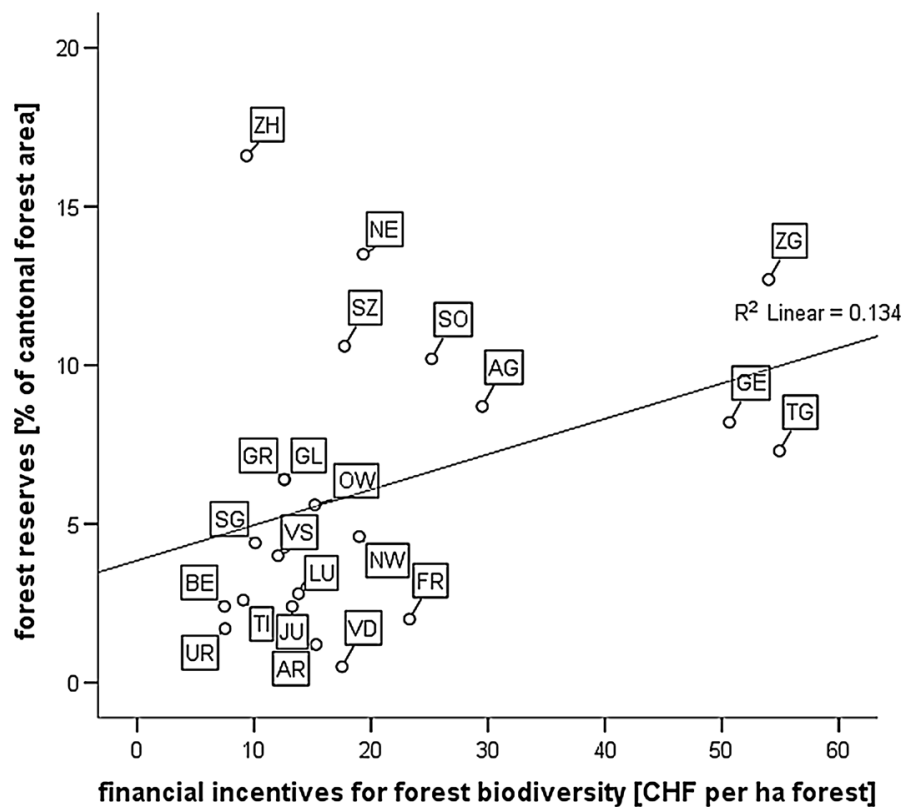

Fig. 2 Dependence of forest reserves on the financial incentives (for forest biodiversity) ( $n=22$ cantons). (The average of the years 2009-2011 was calculated for the financial incentives (of the Confederation and the canton) for forest biodiversity. This average was then divided by the cantonal forest area of 2011. Source Own illustration based on data from BAFU (2009, p. 73, 2010, p. 71, 2011, p. 62, 2012, pp. 14/64)

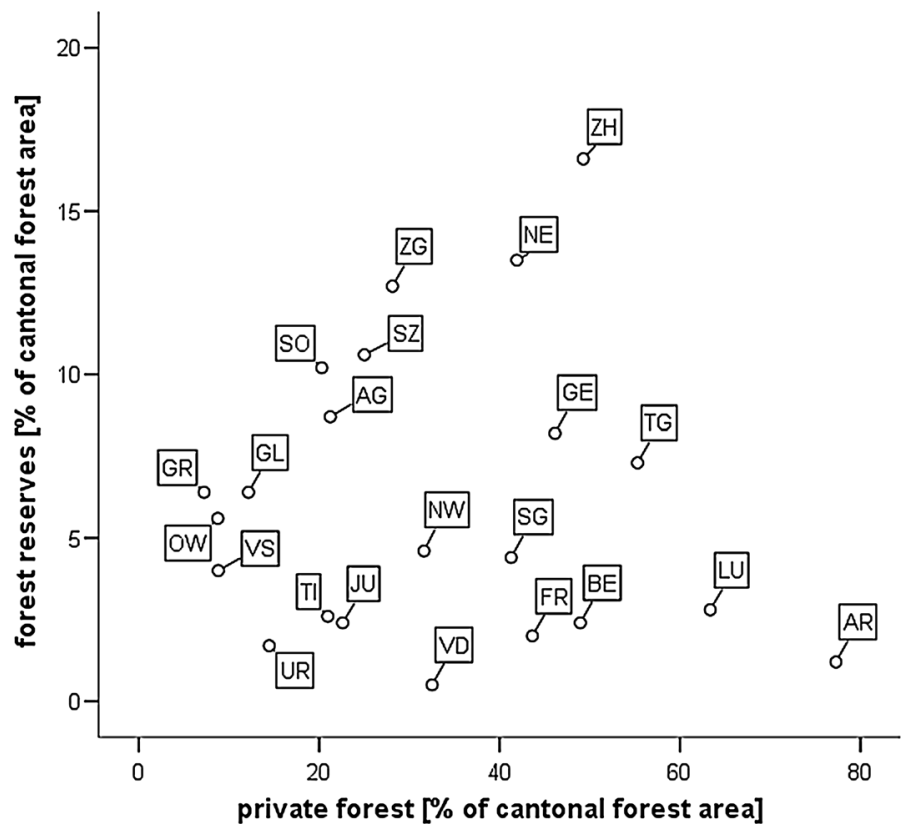

Fig. 3 Dependence of forest reserves on the forest ownership structure (private forest) $(n=22$ cantons). Source Own illustration based on data from Kaeser et al. (2013) and BAFU (2012, p. 14) 


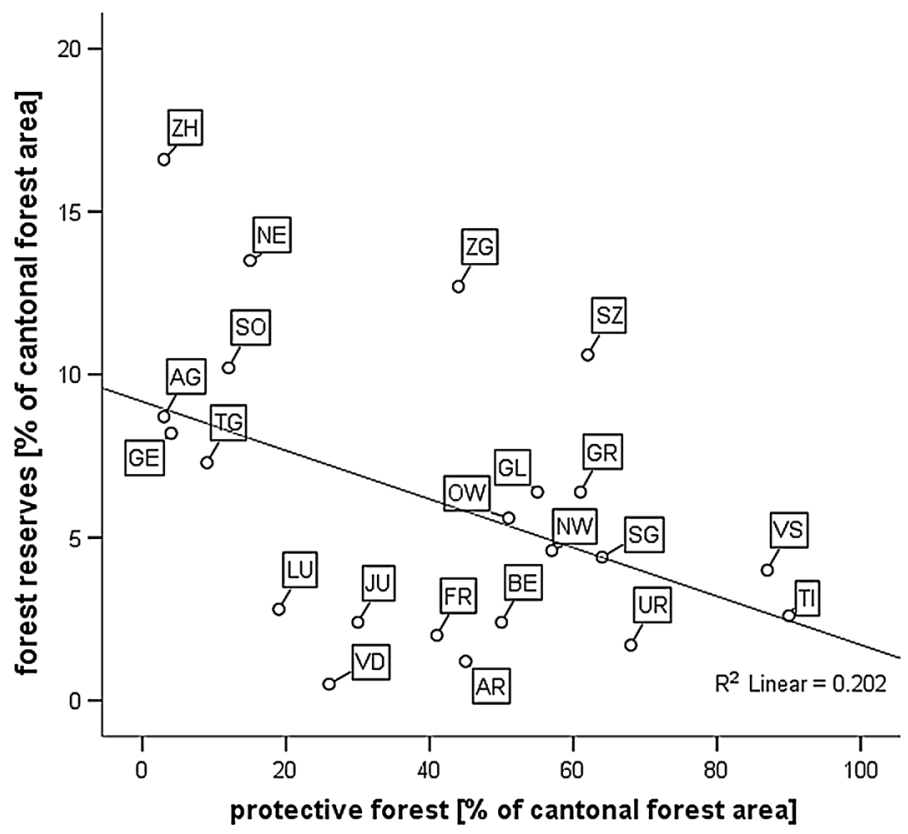

Fig. 4 Dependence of forest reserves on the protective function (protective forest) ( $n=22$ cantons). Source Own illustration based on data from Kaeser et al. (2013) and Losey and Wehrli (2013, p. 20)

protective forest-have delimited more forest reserves than mountainous cantons with lots of protective forest (Fig. 4). Exceptions are the cantons Schwyz (SZ) and Zug (ZG), which have delimited forest reserves in over ten percent of the cantonal forest area, in spite of having more than $40 \%$ protective forest. Yet in general, cantons with a large share of protective forest have delimited less forest reserve area and vice versa. The negative effect of 'protective function' on 'forest reserves' is statistically significant (cf. Table 5). This indicates that the protective function of forests rivals the delimitation of forest reserves in the cantons. In general, the more protective forest a canton has the less forest reserve areas exist.

\section{Discussion}

The Swiss Confederation launched a specific forest reserve policy in cooperation with the cantons in the 1990s. A common forest reserve concept and guidelines were developed, which include financial incentives and should be implemented by the cantons. A decade after the guidelines' elaboration, a survey on forest reserves in 2011 has indicated quite significant differences in delimited forest reserve areas between the cantons. The statistical analysis of the 2011 survey's forest reserve data (in combination with other available data) has shown that the delimited forest reserve areas depend on the financial condition of the canton and the share of protective forest. However, the financial incentives for forest biodiversity (per hectare), the integration of administration (with respect to the topics 
forest biodiversity and protective forest), and the ownership structure (private vs. public forest) have no statistically significant effect on the cantons' delimited forest reserve area.

We discuss our findings from the statistical analysis of the 2011 survey's forest reserve data (in combination with other available data) below. We start with the statistically significant factors, followed by the discussion of the statistically non-significant factors.

Discussion of the statistically significant factors

Our first hypothesis was that if cantons are in a good financial condition, then they have delimited more forest reserve area than cantons in a 'poor' financial condition. The statistical analysis showed that cantons in a good financial condition have delimited significantly more forest reserve areas than cantons with a poorer financial condition. Moreover, the financial condition of a canton is positively correlated with the financial incentives for forest biodiversity (cf. Pearson correlation matrix in Table 4). This indicates that cantons in a good financial condition have higher financial incentives for forest biodiversity. A financially strong canton with a substantial budget may also have more resources for administrative staff in the forest sector and for the consultation of forest owners than a canton with a limited budget. In this sense a good financial condition may lead to more organizational capacity. The cantons' organizational capacities differ and they can 'affect the implementation of nature protection instruments' (Angst 2012, p. 55) e.g. to establish forest reserves.

We also hypothesized that cantons with a large share of protective forest have delimited less forest reserve area than cantons with a low share of protective forest (hypothesis 5). A high share of protective forest is found in the mountainous cantons, whereas only a small proportion of protective forest exists in the lowland cantons of the Midlands. A high share of protective forest has a statistically significant negative effect on the forest reserve area in the cantons. When we consulted experts (seven cantonal head foresters from mainly pre alpine cantons) about the influence of protective forest on forest reserves, they often named the importance of the protective function of forests against natural hazards (high proportion of protective forest) as an inhibiting factor. However, the experts did not name explicit conflicts between forest reserves and the protective function of the forest. Nevertheless, combinations of these on the same forest land are rare in the experts' cantons. This supports the statistically significant negative effect of protective forest on the delimitation of forest reserves mentioned above.

The unpopularity to establish a forest reserve in protective forests may have to do with the philosophy that a protective forest needs tending. Yet according to the former Federal Forest Agency, ${ }^{6}$ the need for maintenance measures in protective forests can be assumed to be smaller the more natural the forests are (Frehner et al. 2005: Annex 5). Whether forest reserves and protective forests are compatible depends on the site conditions (forest types). Forest types whose protective function cannot be improved effectively by forestry interventions (and provided that no technical measures are necessary) pose little potential for conflict between the protective function and forest reserves (Frehner et al. 2005: Annex 5). According to the former Swiss Forest Agency, this applies to forest types whose 'stability is hardly improvable' or whose 'near-natural state usually does not need forestry interventions'. A (one and a half page long) list of forest types in which forest reserves are possible can be found in the guidelines for

${ }^{6}$ The former Federal Forest Agency was integrated in 2006 into today's Federal Office for the Environment. 
protective forest of the former Swiss Forest Agency (cf. Frehner et al. 2005: Annex 5). Furthermore, an internal study by the Federal Office for the Environment has shown that in many situations protective forest and forest reserves are not mutually exclusive (Bolliger et al. 2012, p. 208). According to Ott et al. (1997, p. 69), a considerable share of the mountain forests can ensure stable forest stands on their own, without additional support. Protective forests in the mountains could therefore be increasingly integrated into the forest reserve network (Bolliger et al. 2012, p. 208). However, the support for forest reserves within the population is-according to a recent comprehensive population survey by the Federal Office for the Environment and the Swiss Federal Institute for Forest, Snow and Landscape Research-rather larger in the Midlands than in the Pre-alps (BAFU and WSL 2013, p. 54).

\section{Discussion of the statistically non-significant factors}

The three factors that we have found to have no statistically significant effect on the cantons' delimited forest reserve area in the present study are: the financial incentives for forest biodiversity (per hectare), the integration of administration (with respect to the topics forest biodiversity and protective forest), and the ownership structure (private vs. public forest). In the section below, we discuss these factors one by one and present possible explanations for the statistical insignificance.

The second hypothesis in Table 1 was that cantons with lots of financial incentives for forest biodiversity have delimited more forest reserve area than cantons with few incentives for forest biodiversity. The dependency of the forest reserve area in the cantons on financial incentives for forest biodiversity (per hectare) was not statistically significant; even though the cantons with less than $5 \%$ forest reserve area do not have very high amounts of financial incentives per hectare. We see two possible reasons for this lack of significance: First, the financial incentives for forest biodiversity may in general be too low to have a significant impact on forest reserves' delimitation. From the federal perspective, not enough federal funding has been available for the establishment of forest reserves and for strengthening the financial incentives for the forest owners (Bolliger et al. 2012, p. 208). Moreover, a survey of a representative group of private forest owners in Switzerland showed that 'the impact of financial incentives offered by the government is rather modest' (Zimmermann and Wild-Eck 2007, p. 275). Second, the persuasiveness of the Forest Service (particularly for private forests) could be crucial for the delimitation of forest reserves. The consultation by the local forester seems to be more promising (than financial incentives) to reach the private forest owners (Zimmermann and Wild-Eck 2007, p. 282). Furthermore, when we asked experts (seven cantonal head foresters) about the key factors supporting forest reserves, they named the consultation and the persuasiveness of the cantonal Forest Service, as well as a good relationship between the cantonal Forest Service and the forest owners (respectively that the cantonal Forest Service is perceived as a reliable partner) as being very important. Also according to Zimmermann and Wild-Eck (2007, p. 283), a successful biodiversity policy in private forests is more dependent on the implementation by the cantons than the program structure and the services at the federal level.

The third hypothesis stated that the better forest biodiversity and protective forest are integrated within the cantonal administration, the more delimited forest reserve area exists in the cantons. The integration of administration-i.e. whether the two topics forest biodiversity and protective forest in a canton are dealt with in the same department, office, section or subsection — had no statistically significant effect on the forest reserve area in the 
cantons. This may be due to the fact that these two topics are located in the cantons ubiquitously in the same department and office. Due to this high 'integration of administration', we found rather small differences (at the sectional or sub-sectional level) between the cantonal administrations. Since all cantons have a well-integrated administration (for forest biodiversity and protective forest), this factor may not be suitable to explain the difference in delimited forest reserve area between the cantons. Instead, a possible different weighting of forest biodiversity and protective forest in the cantons could serve as an explanation.

Our fourth hypothesis was that the more private forest area a canton has, the less forest reserve area has been delimited. This is based on our assumption that the small parceled private forest and a lack of motivation of the private forest owners hinders the establishment of (larger) forest reserves. Our assumption was confirmed by the answer we received from experts (seven cantonal head foresters) about forest reserves in their canton: More forest reserves are usually delimited in public forests than in private forests. Most of these experts named the lack of motivation of the private forest owners as an inhibiting factor for creating forest reserves. With respect to the experts consulted, we can say that ownership structure matters and that a large share of public forest seems to be beneficial for the promotion of forest reserves.

However, the performed multiple regression shows a different picture: The ownership structure, i.e. the share of private forest (versus public forest), had a negative, but not a significant effect on the forest reserve area in the cantons. One explanation for this lack of significance could be that public forests comprise the main share of the forests in the cantons and that only three of the considered cantons have more private forests than public forests. Since the public forest is predominant in most of the cantons, the cantonal forest ownership structure may not be able to explain the difference in delimited forest reserve area between the cantons.

Also noteworthy is the negative correlation between private forest and protective forest (cf. Pearson correlation matrix in Table 4). This indicates that protective forests lie mainly in public forests. Protective forest had a significant negative effect on forest reserves in the multiple regression. Thus, we may find less forest reserves in public (protective) forests than expected.

In order to promote forest reserves and forest biodiversity, one option could be that the Confederation and the cantons buy ecologically valuable forest land (cf. Kaeser et al. 2013, p. 12). For the missing large forest reserves, it may be more efficient to focus on the larger public forest than the small-scale private forest, which is also confirmed by the fact that only few private forest owners consider selling their forest (Zimmermann and Wild-Eck 2007, pp. 279/283).

\section{Conclusion}

Our biodiversity study contributes to the discussion on environmental governance (e.g. Jordan et al. 2007; Jänicke and Jörgens 2006), by providing an illustrative example of a policy program with measurable objectives, which is characterized by a cooperative approach and dominated by financial incentives. However, the implementation of this incentive-based policy takes time and quite large differences in forest reserves remain between the cantons. In order to detect the obstacles of implementation, we focused on the policy's outcomes - the forest reserves-and the (presumably) influencing factors. By following the IR approach, which combines property rights and public policies as well as 
user conflicts, we derived our two main hypotheses. Our first main hypothesis was that the institutional framework (financial condition of the cantons and their integration of administration, the instrument financial incentives and the ownership structure of the forest owners) has a substantial impact on the establishment of forest reserves. We performed a multiple regression, which only partially confirmed this hypothesis due to a lack of significance of several factors (see "Discussion"). With respect to the first main hypothesis, only the cantons' financial condition had a statistically significant effect on the delimitation of forest reserve areas. The second main hypothesis stated that the highly subsidized protective function of forests competes with forest reserves for land (as a conflicting service). We found a statistically significant negative effect of protective forest (against natural hazards) on delimited forest reserve areas, which also indicates the indirect effect of topography.

From the multiple regression, we can conclude that in general cantons in a good financial condition and with a small share of protective forest have more forest reserves than cantons in a poor financial condition and with lots of protective forest. That the share of forest reserves of the cantons is largely determined by the different financial and topographic conditions of the cantons is of practical relevance. In our study, we have presented several explanatory approaches for the differences in implementation between the cantons. However, the financial condition of a canton cannot be easily changed. How much protective forest a canton "needs" is also not up for discussion. But there is a certain scope for the question about whether forest reserves and protective forests should be combined more often than is the case currently.

The 2011 survey's results have shown that the objective of 'forest reserves on ten percent of the forest area' until 2030 seems feasible. As long as there is enough forest land to have protective forest and the desired amount of forest reserves separately, there may be no need for action. However, if the situation changes because of the energy transition (e.g. the pressure for wood fuel increases further and starts to interfere with the establishment of forest reserves), we may have to look at other options to achieve the objective of 'forest reserves on ten percent of the forest area'. This is especially true if the existing forest reserves have been delimited in those forests where it was easier (e.g. in large public forest plots with only a few forest owners to convince). One option could be to establish more forest reserves in those protective forests whose forest types are 'suitable', i.e. if forest development cannot be improved effectively by forestry interventions. The combination of protective forest and forest reserves is also interesting in terms of biodiversity since 'protective forests offer special potential for nature protection e.g. due to their generally higher deadwood volumes' (Angst 2012, pp. 3-4). According to the former Federal Forest Agency, a high potential for conservation is often found in forests on less productive sites whose stability is hardly improvable via forestry interventions (cf. Frehner et al. 2005: Annex 5). This implies that those forest types that allow establishing a forest reserve in a protective forest are often valuable for biodiversity. Therefore, if forest reserves and protective forests were combined in a useful way, then this may result in a win-win situation of 'less effort for the management of protective forests' and 'more biodiversity'. In this context, an intense cooperation of the current forest policy 2020 with the national biodiversity strategy is particularly important. How this cooperation takes place and how it can be strengthened is a challenge that requires further research. 


\section{References}

Angst M (2012) Integration of Nature Protection in Swiss Forest Policy. Country report within the framework of the research project integration of nature protection in forest management and its relation to other functions/services. Swiss Federal Research Institute for Forest, Snow and Landscape WSL, Birmensdorf

BAFU (2013) Jahrbuch Wald und Holz 2013. Umwelt-Zustand Nr. 1332. Bundesamt für Umwelt, Bern

BAFU (2012) Jahrbuch Wald und Holz 2012. Umwelt-Zustand Nr. 1224. Bundesamt für Umwelt, Bern

BAFU (2011) Jahrbuch Wald und Holz 2011. Umwelt-Zustand Nr. 1121. Bundesamt für Umwelt, Bern

BAFU (2010) Jahrbuch Wald und Holz 2010. Umwelt-Zustand Nr. 1025. Bundesamt für Umwelt, Bern

BAFU (2009) Jahrbuch Wald und Holz 2009. Umwelt-Zustand Nr. 0925. Bundesamt für Umwelt, Bern

BAFU, WSL (2013) Die Schweizer Bevölkerung und ihr Wald. Bericht zur zweiten Bevölkerungsumfrage. Waldmonitoring soziokulturell (WaMos 2). Bundesamt für Umwelt, Bern; Eidg. Forschungsanstalt für Wald, Schnee und Landschaft, Birmensdorf

Belin D, Kittredge D, Stevens T, Dennis D, Schweik C, Morzuch B (2005) Assessing private forest owner attitudes toward ecosystem-based management. J For 103(1):28-35

BFS (2012) Bildungsfinanzen Ausgabe 2012. Reihe „Statistik der Schweiz“. Bundesamt für Statistik, Neuchâtel

Bolliger M, Imesch N, Schnidrig R (2012) Waldreservatspolitik der Schweiz: Zwischenbilanz und Perspektiven aus Sicht des Bundes (Essay). Schweiz Z Forstwes 163(6):199-209

Boon T, Broch S, Meilby H (2010) How financial compensation changes forest owners' willingness to set aside productive forest areas for nature conservation in Denmark. Scand J For Res 25:564-573

Brändli UB (2010) Schweizerisches Landesforstinventar. Ergebnisse der dritten Erhebung 2004-2006. Eidgenössische Forschungsanstalt für Wald, Schnee und Landschaft WSL, Birmensdorf; Bundesamt für Umwelt BAFU, Bern

Bugmann H, Commarmot B, Meyer P, Heiri C, Wunder J, Matter JF, Brang P (2011) Die Bedeutung von Naturwaldreservaten für die Forschung. In: Brang P, Heiri C, Bugmann H. (Red.) Waldreservate. 50 Jahre natürliche Waldentwicklung in der Schweiz. Eidgenössische Forschungsanstalt für Wald, Schnee und Landschaft WSL, Birmensdorf; ETH Zürich, Zürich. Haupt, Bern Stuttgart Wien, pp 56-71

BUWAL (1998) Konzept Waldreservate Schweiz. Schlussbericht des Projektes Reservatspolitik der Eidgenössischen Forstdirektion, Bundesamt für Umwelt, Wald und Landschaft, Bern

BUWAL, Eidg. Forstdirektion (2002) Leitsätze einer "Waldreservatspolitik Schweiz". http://www.bafu. admin.ch. Accessed 10 May 2011

EFD (2013) EFD Medienmitteilung vom 4. Dezember 2012: Tiefere Steuerbelastung in den meisten Kantonen. http://www.efd.admin.ch. Accessed 29 May 2013

Frehner M, Wasser B, Schwitter R (2005) Nachhaltigkeit und Erfolgskontrolle im Schutzwald. Wegleitung für Pflegemassnahmen in Wäldern mit Schutzfunktion, Vollzug Umwelt. Bundesamt für Umwelt, Wald und Landschaft, Bern

Häfelin U, Müller G, Uhlmann F (2010) Allgemeines Verwaltungsrecht (6. Auflage). Dike Verlag, Zürich St. Gallen

Horne P (2006) Forest owners' acceptance of incentive based policy instruments in forest biodiversity conservation. A choice experiment based approach. Silva Fennica 40(1):169-178

Iftekhar MS, Tisdell JG, Gilfedder L (2014) Private lands for biodiversity conservation: review of conservation covenanting programs in Tasmania, Australia. Biol Conserv 169:176-184

James A, Gaston K, Balmford A (1999) Balancing the Earth's accounts. Governments could safeguard the world's biodiversity with a small fraction of the money they spend on environmentally harmful subsidies. Nature 401:323-324

Jänicke M, Jörgens H (2006) New approaches to environmental governance. In: Jänicke M, Jörgens H (eds) Environmental governance in global perspective: new approaches to ecological and political modernization. Freie Universität Berlin, Berlin, pp 167-209

Jordan A, Wurzel RKW, Zito A (2007) New modes of environmental governance: are New Environmental Policy Instruments (NEPIs) supplanting or supplementing traditional tools of government? In: Klaus J, Biermann F, Feindt PH (eds.), Politik und Umwelt, Politische Vierteljahresschrift, Sonderheft 39:283-298

Kaeser A, Bernasconi J, Zimmermann W (2013) Governance approaches in Swiss forest biodiversity policy: do they really work? For Policy Econ 36:6-13

Kägi B (2002) Umsetzung des Waldreservatskonzepts im Kanton Glarus. Schweiz Z Forstwes 7:274-277

Kissling-Näf I (2000) Wie nachhaltig ist die Schweizer Forstpolitik? Das Nachhaltigkeits-Assessment der Schweizer Forstpolitik: Vorgehen und wichtige Resultate. Schweiz Z Forstwes 151(12):472-479 
Knoepfel P (2003) Anreicherung des IR-Ansatzes durch die Empirie. In: Knoepfel P, Kissling-Näf I, Varone F (Hrsg.). Institutionelle Regime natürlicher Ressourcen in Aktion. Oekologie \& Gesellschaft, Band 19. Helbing \& Lichtenhahn Verlag, Basel, pp 31-58

Knoepfel P, Kissling-Näf I, Varone F (2003) Institutionelle Regime natürlicher Ressourcen in Aktion. Oekologie \& Gesellschaft, Band 19. Helbing \& Lichtenhahn Verlag, Basel

Knoepfel P, Kissling-Näf I, Varone F (2001). Institutionelle Regime für natürliche Ressourcen: Boden, Wasser und Wald im Vergleich. Oekologie \& Gesellschaft, Band 17. Helbing \& Lichtenhahn Verlag, Basel

Losey S, Wehrli A (2013) Schutzwald in der Schweiz. Vom Projekt SilvaProtect-CH zum harmonisierten Schutzwald. Bundesamt für Umwelt, Bern

MCPFE (1993) General Guidances for the Sustainable Management of Forests in Europe. Resolution H1. Ministerial Conferences on the Protection for Forests in Europe, Helsinki

Mutz R (2007) Privatwaldforschung in Deutschland: Überblick und Folgerungen. Schweiz Z Forstwes 158(9):285-292

Ott E, Frehner M, Frey HU, Lüscher P (1997) Gebirgsnadelwälder: Ein praxisorientierter Leitfaden für eine standortgerechte Waldbehandlung. Paul Haupt, Bern

SAEFL (1999) Sustainability Assessment of Swiss Forest Policy: Background Report. Environmental Documentation No. 120 on Forests. Swiss Agency for the Environment, Forests and Landscape, Bern

Schärer W, Jacobi C (2000) Assessment zur Nachhaltigkeit der Schweizer Forstpolitik-Die Sicht der Eidgenössischen Forstdirektion. Schweiz Z Forstwes 151(12):484-488

Schatz B, Gauthier P, Debussche M, Thompson J (2014) A decision tool for listing species for protection on different geographic scales and administrative levels. J Nat Conserv 22:75-83

Weiss G, Hogl K, Rametsteiner E, Sekot W (2007) Privatwald in Österreich—neu entdeckt. Schweiz Z Forstwes 158(9):293-301

Zimmermann W, Wild-Eck S (2007) Struktur, Verhalten und Einstellung von Schweizer Privatwaldeigentümern. Schweiz Z Forstwes 158(9):275-284

Zingerli C, Zimmermann W (2006) Ansätze moderner politischer Steuerung in der Schweizer Waldpolitik. Schweiz Z Forstwes 157(1):8-16

\section{List of cited legal acts}

SR 921.0 Federal Law on Forests (Law on Forests, WaG) of 4 October 1991

SR 921.0 Federal Act on Forest (Forest Act, ForA) of 4 October 1991 (Status as of 1 January 2008)

SR 921.01 Ordinance on Forest (Forest Ordinance, WaV) of 30 November 1992

SR 921.01 Ordinance on Forest (Forest Ordinance, ForO) of 30 November 1992 (Status as on 1 March 2011)

SR 613.11 Verordnung über die Festsetzung der Finanzkraft der Kantone für die Jahre 2006 und 2007 vom

9. November 2005 (Stand am 29. November 2005)

AS 20075779 Bundesgesetz über die Schaffung und die Änderung von Erlassen zur Neugestaltung des Finanzausgleichs und der Aufgabenteilung zwischen Bund und Kantonen (NFA)

AS 20075823 Verordnung über Anpassungen des Verordnungsrechts an die Neugestaltung des Finanzausgleichs und der Aufgabenteilung zwischen Bund und Kantonen vom 7. November 2007 